Article

\title{
The Illiberal Turn or Swerve in Central Europe?
}

\author{
Lenka Bustikova $^{1, *}$ and Petra Guasti ${ }^{2}$ \\ ${ }^{1}$ School of Politics and Global Studies, Arizona State University, Tempe, AZ 85287, USA; E-Mail: lenka.bustikova@asu.edu \\ 2 Democratic Innovations Unit, Goethe University Frankfurt, 60329 Frankfurt am Main, Germany; \\ E-Mail: guasti@soz.uni-franfkurt.de
}

* Corresponding author

Submitted: 4 September 2017 | Accepted: 22 November 2017 | Published: 29 December 2017

\begin{abstract}
Scholars are coming to terms with the fact that something is rotten in the new democracies of Central Europe. The corrosion has multiple symptoms: declining trust in democratic institutions, emboldened uncivil society, the rise of oligarchs and populists as political leaders, assaults on an independent judiciary, the colonization of public administration by political proxies, increased political control over media, civic apathy, nationalistic contestation and Russian meddling. These processes signal that the liberal-democratic project in the so-called Visegrad Four (the Czech Republic, Hungary, Poland and Slovakia) has been either stalled, diverted or reversed. This article investigates the "illiberal turn" in the Visegrad Four (V4) countries. It develops an analytical distinction between illiberal "turns" and "swerves", with the former representing more permanent political changes, and offers evidence that Hungary is the only country in the V4 at the brink of a decisive illiberal turn.
\end{abstract}

\section{Keywords}

Czech Republic; democracy; democratic consolidation; Eastern Europe; Hungary; illiberalism; nationalism; Poland; populism; Slovakia

\section{Issue}

This article is part of the issue "Populism and the Remaking of (II)Liberal Democracy in Europe", edited by Lars Rensmann (University of Groningen, The Netherlands), Sarah L. de Lange (University of Amsterdam, The Netherlands) and Stefan Couperus (University of Groningen, The Netherlands).

(C) 2017 by the authors; licensee Cogitatio (Lisbon, Portugal). This article is licensed under a Creative Commons Attribution 4.0 International License (CC BY).

\section{Introduction}

On October 19, 2017, a 54-year old chemist set himself on fire in Warsaw to protest the dismantling of democracy in Poland. Piotr Szczęsny died from his injuries ten days later (Dyke, 2017; Nalepa, 2017). His death symbolizes the decay of the democratic order in the so-called Visegrad Four (V4) - the Czech Republic, Hungary, Poland and Slovakia-the symptoms of which include declining trust in democratic institutions, emboldened uncivil society, the rise of oligarchs and populists as political leaders, assaults on an independent judiciary, the colonization of public administration by political proxies, increased political control over media, civic apathy and nationalistic contestation. ${ }^{1}$ These processes signal that the liberal-democratic project in these polities has been either stalled, diverted or reversed. ${ }^{2}$

Although the extent of democratic decay in each of the V4 countries varies, the notion of a turn from liberalism and pluralism (an "illiberal turn") presumes the existence of a more or less linear trajectory and a consolidated democratic system from which recent events are

\footnotetext{
${ }^{1}$ On disruptions see Bernhard and Karakoç (2011); Hanley and Sikk (2016); Deegan-Krause and Haughton (2009); Haughton and Deegan-Krause (2015); Stanley and Czesnik (2016); Stanley (2008); cf. Kitschelt, Mansfeldova, Markowski and Toka (1999).

2 On backsliding see Dawnson and Hanley (2016); Greskovits (2015); Huq and Ginsburg (in press); Rupnik (2007); Hanley and Vachudova (2017); cf. Grzymala-Busse (2017); Levitz and Pop-Eleches (2010); Pop-Eleches and Tucker (2017).
} 
seen as backsliding. We challenge this view. Rather than seeing the V4 as having made a decisive break from an inexorably liberal trajectory-an illiberal turn-we suggest that recent developments in the political systems of the V4 countries bear out a different-albeit no less meaningful and consequential-model of change, characterized by a sequence of "episodes", some of which can be characterized as "illiberal swerves". In those cases in which swerving has persisted, we can speak about an "illiberal turn". In developing this argument, we build on Bernhard's concept of chronic instability (Bernhard, 2015), which allows us to investigate the limits of path dependence. If we hone in on shorter temporal sequences, marked by elections, rather than on tectonic shifts in regimes, we can better distinguish illiberal swerves from outright turns, thereby sharpening our analytical lens on recent developments in the V4.

We view the sequences of electoral cycles as a series of inherently unstable liberal-illiberal pushes and pulls, which signal shifts in domestic and international factors (Thelen, 2003). Discussions of the so-called "illiberal turn" often rely on the concept of backsliding (cf. Greskovits, 2015; Jasiewicz, 2007), which can be distinguished from swerving in at least two ways. First, backsliding implies falling off a liberal democratic trajectory and gives the impression that the liberal project has been largely implemented and stable. The concept of swerving allows for the possibility that the commitment to democratic pluralism has weakened, without implying an idealized anchor-point. Swerving recognizes volatility and uncertainty as an integral part of democracy, without necessarily drawing an immediate link to a regime change. Second, backsliding assumes the independence of a string of observed sequences like a Markov process. But the trajectory of illiberal swerving depends on previous episodes, and indeed is often a reaction to the previous punctuated episode(s) of a liberal expansion (Bustikova, 2014). Moreover, the current revolt against liberalism is not only a revolt against the values of liberalism but also a reaction to (some of) the hypocritical advocates of liberalism who used it as a cover to steal and to amass influence.

At a time when considerable attention is devoted to the agency of political leaders and elite manipulation of the masses, it is crucial to acknowledge that shifts towards less liberal polities are often enacted by popular demand and enthusiastically supported by illiberal "uncivil" society (Chambers \& Kopstein, 2001; Kopecky \& Mudde, 2003). The tail is also wagging the dog. Political leaders do not typically "hijack" polities. Instead, they modify them within the constraints imposed by legacies, institutions, the political opposition and the voters.

By recalibrating the focus from backsliding and illiberal turns towards swerves, we can more easily see how and when all four countries have converged or diverged over time. From a historical perspective, the immediate post-1989 period gave rise to an episode of "imitative modernization", in which all four countries mim- icked the idealized template of the liberal democratic, pluralistic polity of the West. Sovereignty issues were suppressed in pursuit of a "return to Europe". Slovakia tested the boundaries of illiberal swerving first. It swiftly diverged from liberalism when it embraced the authoritarian nationalism of Mečiar (1994-1998), but has rebounded. Facing a serious threat of being left behind during the first wave of enlargement in 2004, along with potential negative economic consequences, Slovakia has seen darker days already and may therefore be more inoculated from a future illiberal turn than Poland, the Czech Republic, and Hungary, which did not experience anything comparable in the 1990s. Whereas the October 2017 Czech elections saw growing support for populist (almost $30 \%$ ) and radical right (10.6\%) forces, the November 2017 Slovak regional elections saw the victory of a coalition of right-leaning forces defeating both the populist center-left and the extreme right. Slovakia returned to the liberal path with a vengeance and is currently swerving the least among the V4 countries.

Executive aggrandizement (Bermeo, 2016) has also succeeded the least in Slovakia and the Czech Republic compared to Poland and Hungary, which have gone much further in degrading democratic institutions, such as courts and public administration. In Poland, the first Polish Law and Justice (PiS)-led government (2005-2007) attempted to impose its centralized and illiberal vision of the state but struggled to overcome political issues within the governing coalition and the staunch opposition of the Constitutional Tribunal. The Polish swerve lasted one electoral cycle and was reversed. The second $\mathrm{PiS}$ government (2015-) has been more successful in realizing this vision but faces opposition from civil society and to a lesser degree from the President, who vetoed two bills designed to control the Constitutional Tribunal. However, the strength of illiberal civil society was manifest on October 11, 2017, when some 60,000 patriots marched in Warsaw to celebrate the Day of Independence, calling for a "white Europe" and a "Poland without Jews and Muslims".

In Hungary, executive aggrandizement and swerving over two electoral cycles (2010 and 2014) has resulted in the only fully illiberal turn in the V4. The Orbán government has used its supermajority to raise issues of national sovereignty and to attack liberal civil society. This has facilitated a concentration of executive power, enabling the ruling party FIDESZ to mold the country and polity in its image, while keeping its political opponents down. Already in 2012, Hungary amended its constitution to significantly weaken the ability of the Constitutional Court to strike out laws. In 2017, the government set impossible conditions for Central European University to remain in the country.

The notion of swerves-defined as volatile episodes - permits us to identify both similarities and differences across time and countries. After distinguishing between illiberal swerves and illiberal turns, we suggest that Hungary is the only country in the V4 at the brink of an il- 
liberal turn, whereas Poland and to a significantly lesser degree the Czech Republic and Slovakia are engaged in illiberal swerving. It is too early to tell whether these will transform into fully illiberal turns. For a country's sequence of swerves to become a turn, our framework suggests that three conditions must be satisfied:

1) Executive aggrandizement;

2) Contested sovereignty that increases polarization;

3) Dominant party winning two consecutive elections.

The next section describes these three conditions in further detail.

\section{Illiberal Swerves and Turns}

We define illiberal swerving using the first two conditions: executive aggrandizement and contestation of sovereignty. Aggrandizement refers to an increase in the concentration of political power (Bermeo, 2016). It undermines the constitutional order and reduces checks and balances. If sovereignty becomes contested, often with the help of populist appeals, ethnic, religious and social minorities can face exclusion from the sovereign. This limits pluralism in political deliberations. An illiberal turn follows if the first two conditions are present and a dominant party confirms its course in two consecutive elections.

Attempts to concentrate power are not new to the V4 region. In Slovakia, Mečiar's attempt at establishing a nationalist, centralized and illiberal political system failed as a result of domestic and international pressure. This took place before Slovakia's accession to the EU, giving the EU significant leverage in thwarting it (Vachudova, 2005). In the Czech Republic, one episode of a failed power grab is particularly important: the Opposition Agreement of 1998 , an attempt by two major parties to strengthen the majoritarian character of the Czech polity. This gambit failed due to political opposition and the Constitutional Court (2000). Similarly, in Poland, the first PiS-led government's (2005-2007) swerving was blocked by the Constitutional Tribunal.

Sovereignty becomes contested if a polity perceives itself to be under threat, whether real or fabricated by swerving elites. The sovereign is often a native ruler, defined in ethnic terms, but the boundaries of the sovereign are fluid. The views of who does-and does not-constitute the sovereign changes over time and differs across countries (Basta \& Bustikova, 2016; Shelef, 2010; Siroky \& Cuffe, 2015). Non-politicized minorities (for example, Vietnamese or Chinese minorities in the V4) can be subsumed by the sovereign. For example, the Czech far-right leader Okamura is ethnically half Japanese. Social, religious and sexual minorities can be excluded from membership in the sovereign, especially if they seek an expansion of rights (Bustikova, 2014, 2015). The boundaries of the sovereign are contextual, defined by historical experiences and shaped by domestic and international constraints.

When sovereignty becomes contested, support for radical right parties often follows. An illiberal swerve cannot be accomplished without access to power, which is limited for most niche parties. Radicalized mainstream parties, on the contrary, are in a prime position to combine exclusionary identity politics with executive aggrandizement (Bustikova, in press). However, if mainstream parties are perceived as having betrayed the sovereign, new, niche parties gain support. This implosion manifests itself in a decrease in support for existing political parties and the emergence of new, populist parties (e.g., ANO 2011, SMER).

Contested sovereignty has therefore contributed to the success of radical right parties, including Okamura's Dawn of Direct Democracy, which entered the Czech Parliament in 2013, Okamura's Freedom and Direct Democracy, which entered in 2017, Kotleba's Our Slovakia, which entered Slovak Parliament in 2016 and Hungary's Jobbik, which is poised to win seats, again, in the 2018 Hungarian elections. ${ }^{3}$ In the 2017 Czech elections, the radical right increased its presence in the Parliament and is pushing for a Czexit-a referendum on the EU membership. The nationalist Eurosceptic, Václav Klaus Jr., ran on the ballot of his father's former party (ODS) and won the second highest number of preferential votes (after Andrej Babiš). The leader of ANO, Babiš, however, like all other mainstream parties, expressed clear support for EU membership. Poland has seen two waves of a populist and radical right insurgency. First, the radicalright Catholic nationalist League of Polish Families (LPR) and the agrarian populist Self-Defence (SRP) emerged in 2001. The nationalist, conservative and economically libertarian Kukiz'15 movement followed in 2015.

Uncivil society (illiberal civil society) is an important ally of the Polish, Hungarian and to a lesser degree Slovak and Czech swerving leaders. ${ }^{4}$ Government-controlled media outlets in Poland, Hungary and Slovakia-and Babiš's media in the Czech Republic-regularly attack organizations of civil society as "foreign agents" intent on undermining national sovereignty (Guasti, 2016). In Hungary, Orbán pioneered attacks on civil society by tightening rules on NGOs, often with foreign links and funding sources. ${ }^{5}$ Orbán also launched a campaign against Central European University and its founder George Soros. In a "national consultation" about the future of Hungary, George Soros was linked to the refugee crisis and Islamization of Europe. FIDESZ hopes that xenophobic mobilization, and the votes of Hungarians living abroad, will help the party to win the upcoming elections in 2018. Un-

\footnotetext{
3 Jobbik has however recently moved to the center, runs on an anti-corruption platform that targets FIDESZ. On refugees, Jobbik embraces a more centrist view, to distance itself from FIDESZ. Paradoxically, Jobbik might present a challenge to FIDESZ's desire to capture a supermajority in the 2018 parliamentary elections.

${ }^{4}$ Anti-Semitism has also grown in V4 and has been strategically adopted over time to portray Jews as a "fifth column" (Bustikova \& Guasti, 2012).

5 Than and Dunai (2017); United Nations High Commissioner for Refugees (2017).
} 
civil society has created an atmosphere in which racists, nationalists, and ethno-populists can articulate exclusionist narratives targeted at vulnerable groups, such as ethnic minorities and refugees, raise militias to protect the borders, promote extreme religious conservatism (anti-abortion, anti-LGBT rights), and attack the "EU's multiculturalist propaganda".

In Slovakia, uncivil society had focused much of its attention initially on the Hungarian minority but shifted to social and religious issues. This resulted in initiatives like the 2009 language law and the 2015 referendum on gays and lesbians (L'udová strana Naše Slovensko). ${ }^{6}$ For the time being, the Hungarian minority is being accommodated. In Hungary, the main targets of the radical right have tended to be Roma, and from 2015 onwards refugees, with the crisis of 2015 ramping up the mobilization of uncivil society against refugees and facilitating general expressions of racism. The Hungarian government stokes fear and sanctions physical attacks and abuse of refugees by border guards, especially at the Serbian border. ${ }^{7}$

In Poland, the most successful organization in this respect is the Catholic-nationalist network around the Radio Maryja radio station, which has forged a synergistic political-economic relationship with PiS. As a mainstream radicalized party, PiS is powerful enough to put the religious conservative agenda into legislation. PiS has also capitalized on the organizational capacities of farright organizations, such as the National-Radical Camp (ONR) and the All-Polish Youth (Młodzież Wszechpolska). But rather than co-opting them into mainstream politics, PiS has been content to benefit from associating themselves with the actions of these organizations, while keeping sufficient distance to deny responsibility for some of the more overtly racist elements of their agenda. ${ }^{8}$

In the Czech Republic, uncivil society currently manifests itself in the "Block against Islam" (established in 2015) and in the 2017 "Manifesto of the White Heterosexual Man". Unlike in the remaining three V4 countries, Babiš has so far resisted open cooperation with such organizations. Before the elections, Babiš rejected a governing coalition of ANO with the far right and unreformed communists. However, after the election, ANO has aligned its votes with them and placed far right representatives and communist MPs in charge of key parliamentary committees.

All four V4 political leaders (Babiš and Kaczyński) and Prime Ministers (Fico and Orbán) differ in the degree to which they embrace executive aggrandizement and emphasize sovereignty. The major dividing line between Babiš, the designated Prime Minister as of the October 2017 election, and the leaders of Slovakia, Poland and Hungary is the absence of an exclusionary approach to ethnic and social minorities, which indicates that sovereignty is not at the core of Babiš's political platform. However, Babiš is aligned with President Zeman who strategically polarizes the electorate using nativist hate speech against refugees and Islam. Babiš's hesitation to fully embrace the rhetoric of contested sovereignty stands in stark contrast to the other V4 members, where the issue of sovereignty has been more politically salient.

At present, Slovakia stands out as the only country of the V4 in which calls for a significant expansion of executive power are absent. This is at least in part attributable to the need to build coalitions to govern effectively, which makes the concentration of power much less feasible. Mobilization against Hungarians has subsided over the past five years, and the focus has shifted to Roma, LGBT, and refugees. In contrast to Poland and Hungary, the leadership in Slovakia is currently not on a mission to concentrate executive power and modify majority-minority relations. Despite the prominence of Catholic faith and a politically active Catholic church, Slovakia is not bitterly divided over social and religious issues to the degree in Poland. The current Prime Minister Robert Fico is ruling over an ideologically incoherent coalition that represents the radical right and ethnic Hungarians in the same cabinet. Fico is therefore content with the status quo and has no grandiose plans other than to keep two far-right parties at bay by strategically adopting their rhetoric.

In the Czech case, Andrej Babiš's populist political party ANO won in a landslide with almost $30 \%$ of the vote in October 2017. Babiš views politics in technocratic terms and sees the "state as a firm" in which the business of government is not impeded by democratic deliberation in the parliament. He envisions a polity where executive power is highly centralized, preferably in his hands. He aims to run a "semi-technocratic government", constituted by a mixture of ANO ministers and experts. So far, most experts that have been offered ministerial posts have declined. Civil society has also pushed back. Constitutional scholars have rebuked the President Zeman's attempt to interpret the Constitution in a way that would allow Babiš to run a minority government without winning a vote of confidence and thereby subvert the parliament.

The major difference between Poland and Hungary is that the Law and Justice party (PiS) faces a more significant parliamentary and extra-parliamentary opposition to its vision of a homogenous sovereign. While the governments of Poland and Hungary share a similar desire for a power grab, Kaczyński is an ideologue aligned with the church, whereas Orbán is a corrupt ideological entrepreneur aligned with oligarchs. ${ }^{9}$ Orbán has been explicit in his view that ethnic, religious and sexual minorities should not have an equal opportunity to determine the direction of the Hungarian state: "Hungary is a se-

\footnotetext{
${ }^{6}$ Passed in 2009 by, PM Fico government, the law declared that the Slovak language is an articulation of national sovereignty, Slovak must be used in all official settings, including at the local government level, and severely restricted the use of minority languages (Bustikova, 2015).

${ }^{7}$ Medecins Sans Frontieres (2016); Dearden (2017). Discussions with Aron Suba.

8 Personal communication by Benjamin Stanley.

${ }^{9}$ On inquiry into Orbán by the EU anti-corruption body, OLAF see Nolan (2016).
} 
rious country. It is fundamentally based on traditional values. Hungary is a tolerant nation. Tolerance, however, does not mean that we would apply the same rules for people whose lifestyle is different from our own. We differentiate between them and us". ${ }^{10}$

Current developments in Poland are serious. The leader of the PiS party, Jarosław Kaczyński, already holds executive power despite having no formal executive title. PiS deputy, Beata Szydło, who came to power after PiS won a majority of seats in the October 2015 parliamentary election, is widely regarded as a prime minister in name only. Szydło's government swiftly embarked on a path of concentrating power in the hands of the PiS-attacking the independence of the Constitutional Tribunal and the judiciary, and undermining the impartiality of the public administration and public media. The implementation of this project has generated a significant backlash on the part of Polish civil society, external institutions (in particular, the European Commission) and the Polish President, Andrzej Duda (PiS), who vetoed two governmental bills aimed at increasing control over the judiciary. It is not clear whether Jarosław Kaczyński will succeed in implementing his illiberal vision into a fully illiberal turn, or whether Polish swerving will ultimately be diluted, as a result of either opposition or internal PiS power struggles.

Orbán in Hungary has made the most significant steps in an illiberal direction. Orbán and his party FIDESZ have been able to concentrate power gradually over the past seven years, and have successfully reshaped the Hungarian polity. Orbán's playbook (Zalan, 2016) has provided a blueprint for the other V4 countries, particularly for Poland. ${ }^{11}$ Orbán seized control of the Constitutional Court and the Central Bank, politicized public administration, and intimidated FIDESZ's political opponents. Orbán's centralization of power and the establishment of an "illiberal democracy" in Hungary has proceeded largely unchecked by opposition forces. Orbán has also been able to skillfully use the EU structural funds to shore up the Hungarian economy, his dominant party FIDESZ, and its oligarchic cronies.

Having characterized the extent of illiberal swerving and turning in the $\mathrm{V} 4$, we next turn our attention to the relationship between illiberal swerving and the EU.

\section{Illiberal Swerving and the EU}

The EU represents the most significant external power to influence the polities of the V4 countries after 1989.
Using both positive incentives and conditional pressures, the EU has influenced Central and Eastern European (CEE) countries in political, economic and constitutional terms. This has been both directly via legislation (acquis communautaire), and indirectly, via agenda-setting and institutional adaptation (Lewis, 2006; Malová et al., 2010). To the extent that the EU has been effective, the asymmetrical relationship between the CEE applicant countries and the EU seems to have provided it with its leverage (Vachudova, 2015; cf. Grzymala-Busse \& Innes, 2003; Guasti, Siroky, \& Stockemer, 2017). In particular, EU conditionality and leverage was applied differentially-weaker pressure was put on the leaders and stronger pressure on the laggards (Schimmelfennig, 2005).

It is tempting to see the current illiberal swerving as a "natural correction" to the "overshooting" of European liberalism. It would be erroneous to suggest that the reforms of the past two decades constituted an attempt to impose upon Central Europe a set of solutions, which were somehow "alien" to the region, and not reflective of what at least some of the political class and the broader public desired. Rather than impugning the EU for the illiberal turn (Schlipphak \& Treib, 2017), or for its inability to thwart it (Jenne \& Mudde, 2012; Rupnik, 2016), we should consider the possibility that the accession process empowered political elites and civil society in V4 to take ownership of the European integration process. Some have embraced it; others seek more distance. As an elite-driven process, however, the EU enlargement facilitated both liberal and illiberal power grabs.

To illustrate episodic swerving over time, we turn to the World Governance Indicators, which offer the longest view on the V4 countries (Figure 1). We recode the data using Hagopian's (2005) three dimensions of strength, effectiveness, and constitutionalism of democracy to highlight the similarities and the differences between the V4 countries over time. ${ }^{12}$ Figure 1 shows the pre-accession (2004) divergence between the $\mathrm{V} 4$ and an overall improvement over time, but the development is not linear in any of the four countries. Figure 1 also shows that illiberal swerving is not new: there have been previous dips in the governance metrics. Finally, it also shows that illiberal swerving is temporary. Only Hungary has arguably made an illiberal turn.

Epstein and Sedelmeier (2008) contend that the EU accession improved the general institutional infrastructure and the legislative capacity of CEE countries. We find supportive evidence in three out of four cases in the V4.

\footnotetext{
10 May 2017 speech, available at http://hungarianspectrum.org/2015/05/22/viktor-orban-hungary-is-a-serious-country-where-gays-are-patiently-tole rated

${ }^{11}$ Zalan outlines a guidebook for an illiberal democracy. It consists of these following steps: win elections promising glory, dismantle courts, modify the constitution, take over the state media, eliminate the power of foreign investors, discredit the opposition and the civil society, change the electoral rules (Zalan, 2016).

12 To demonstrate the effect of EU conditionality we follow Hagopian (2005) and measure three dimensions of democratic quality-strength, effectiveness, and constitutionalism. We transform the six governance dimension of the World Governance Indicators (WGI) into three dimensions: WGI's voice and accountability and political stability as a strength of democracy; governance effectiveness and regulatory quality as democratic effectiveness; the rule of law and control of corruption as constitutionalism. We select WGI as it offers the longest sequence of indicators for the CEE region. The period between 1996 to 2015 encompasses both the pre-accession, accession and post-accession. We acknowledge that quality of democracy and quality of governance are overlapping concepts.
} 


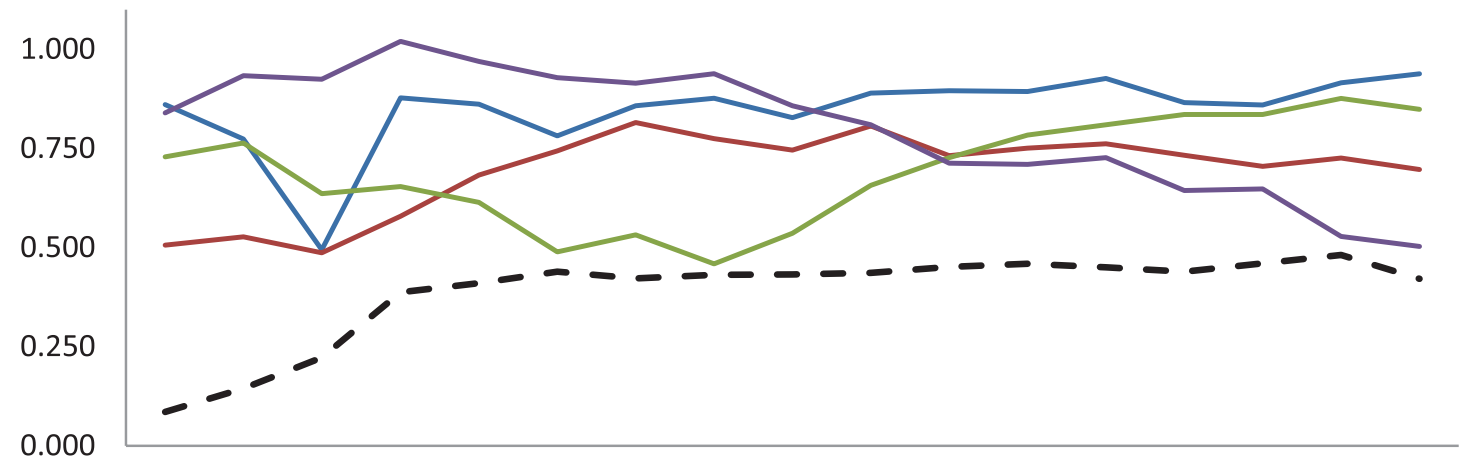

19961998200020022003200420052006200720082009201020112012201320142015

$\begin{array}{lll}\text { Czech Republic } & \text { Slovakia } \\ \text { Hungary } & \text { All NMS avarage }\end{array}$

Figure 1. Comparison of Governance in V4 countries between 1996 and 2015. Source: World Governance Indicators. Notes: New member states averages is based on calculations of the authors. All new member states average includes all new member states of the EU (enlargements 2004, 2007 and 2013: Bulgaria, Croatia, Czech Republic, Estonia, Hungary, Latvia, Lithuania, Poland, Romania, Slovakia and Slovenia). Lower scores are associated with swerving.

In Hungary, all democratic indicators decreased between 1996 and 2015. Over time, Hungary performed best in 2002 and 2003 (the height of the EU pre-accession leverage) and worst in 2015 as PM Orbán continued his construction of an "illiberal democracy". In Poland and Slovakia, all indicators have strengthened over time. Slovakia was the second weakest of the V4 in 2015, but the reason lies in its unfavorable 1996 ranking-significantly lower than that of the other V4 countries. Slovakia started as a laggard, and over time experienced significant growth and improvement. Its strongest year was 2005 (the "catch-up" period) and its weakest year was 2000 (Fico's first government).

Poland seems to be immune to swerves, but its development has been exceedingly volatile: negative between 2004 and 2006 (first PiS term) and positive in 2014 (before the crumbling of the Civic Platform). Given the significant progress that the Law and Justice government has made in implementing its illiberal reform program, the 2016-2017 data for Poland will certainly reflect this decline. ${ }^{13}$ The Czech Republic was the strongest performer of the V4 group in both 1996 and 2016. The dip between 1996 to 1998 is due to the Opposition Agreement, which was a failed attempt by the two major political parties to transform the Czech political system by strengthening its majoritarian elements. Similar to Poland, we expect a sharp downward trajectory after the October 2017 electoral victory of ANO.

Illiberal swerves are episodic, temporary and reversible, whereas illiberal turns represent more permanent shifts in the state's political orientation. While Poland, the Czech Republic and especially Slovakia have improved over time, whether despite or because of illiberal swerving, Hungary has worsened over time.

\section{Illiberal Swerving and Refugee Crisis}

The refugee crisis increased contestation over sovereignty issues and polarized the electorate. Driven by populist political voices and unbalanced media reporting, public opinion in all V4 countries is strongly opposed to the reception and integration of refugees (Guasti, 2017). Opposition to the EU refugee relocation quotas is usually couched in logistical terms-CEE countries are not prepared to integrate migrants, it is argued. Others argue that Muslim immigration represents a security threat and a health risk. These arguments persist in spite of the fact that V4 countries have previously integrated migrants without significant difficulties. The Czech Republic integrated thousands of migrants from Bosnia (Muslims) and Ukraine and Moldova in the 1990s. Poland has taken in thousands of Chechen refugees (Muslims) over the last two decades. Hungary was the second largest recipient of refugees from the Yugoslav wars. None of these actions led to political polarization. The number of refugees seeking asylum in the all V4 countries after 2015 seems well within these limits. And still, the salience of the national sovereignty issues has increased significantly, and national politicians have turned against the EU to stay in power.

In 2016, the EU tried to introduce quotas for the distribution of refugees to various countries but met with strong opposition from Hungary, Slovakia, the Czech Republic (and Romania). In May 2017, the Hungarian and Slovak governments disputed the EU refugee quotas at the European Court of Justice, arguing that the quotas are a pull factor for refugees, that they exceed the powers of the EU and that they undermine the sovereignty of CEE states. In July 2017, the European Court of Justice

\footnotetext{
13 We expect most indicators to decrease significantly, reflecting the multi-faceted character of the PiS project, targeting the country's Constitutional Tribunal, judiciary, public media, public administration and the armed forces, and indication private media and non-governmental organizations will become targets in the near future.
} 
upheld the mandatory refugee relocation quotas and the EU Commission sent a formal request to the Czech Republic, Hungary, and Poland-the three countries currently in breach of their legal obligations - to begin complying with the quotas. Poland and Hungary have so far refused to take any asylum-seeker under the EU scheme, while Slovakia and the Czech Republic have taken in some refugees, but continue to cite security concerns.

Populists and radical right groups have been at the forefront of developing negative narratives about the consequences of accepting refugees. Many V4 politicians (for example, Czech President Zeman and Polish PiS leader Kaczyński) have drawn a clear link between the presence of refugees in Europe and the increased risk of terrorist attacks. Every terrorist attack in Western Europe is presented as proof of a security threat. In January 2016, then Czech Minister of Finance Andrej Babiš summarized these arguments on his Twitter account: "When you see today that more advanced countries, with a different tradition of receiving migrants, are not able to integrate migrants from the Middle East and Africa, then you cannot be surprised that I do not accept any refugees. I honestly do not believe that they can integrate into our society".

Populists and radical right actors grasp this opportunity to strengthen their anti-establishment rhetoricpresenting the disease (governmental elites as corrupted by the EU, and unable to defend national interests) and the cure (populist representatives of the people, who will effectively push back against "Brussels" and the dangers of multiculturalism). The 2015 elections in Poland demonstrated the potency of the refugee issue as an electoral asset for mainstream parties in Poland. PiS exploited public anger at the outgoing Civic Platform government-which had voted in favor of the refugee quotas - to increase its appeal to voters on the right and also to center-right voters whose concerns were rooted in fears about the consequences of immigration.

Campaigning against refugees backfired against the mainstream SMER in Slovakia when it tried to outbid the far right on the refugee issue. The increased salience of refugees strengthened far-right parties, which cumulatively obtained $16 \%$ of the vote. ${ }^{14}$ The strategy of Fico's SMER weakened his dominant position in Slovak politics. In the 2017 Czech elections, campaigning against refugees also backfired on the mainstream Social Democrats, who lost $70 \%$ of their support, and strengthened the radical right, who went from $6.9 \%$ in 2013 to $10.6 \%$ in 2017.

The illiberal swerve has a less off mentioned liberal twin, characterized by an embrace of the European project and its democratic values. Amid the populist antirefugee rhetorical storm, Slovak President Andrej Kiska was alone among the V4 leaders in his appeal to the public to show openness, solidarity, and humanity, and to refrain from racism. More importantly, Kiska said: "I perceive the debate we lead about migrants and refugees as an important struggle for the heart and character of Slovakia". The same can, of course, be said for the other V4 countries, but major politicians defending liberal cosmopolitan values are in short supply in the rest of the CEE.

Still, the European project has not been rejected. Most citizens in the V4 trust the EU more than their governments. Second, V4 citizens trust the EU more than the citizens of an average EU country (Figure 2). In October 2004, several months after the accession of the first CEE wave, more than half of V4 citizens trusted the EU. Hungarians trusted the EU the most (63.5\%), followed by the Slovaks (61.3\%), and the Poles and the Czechs the

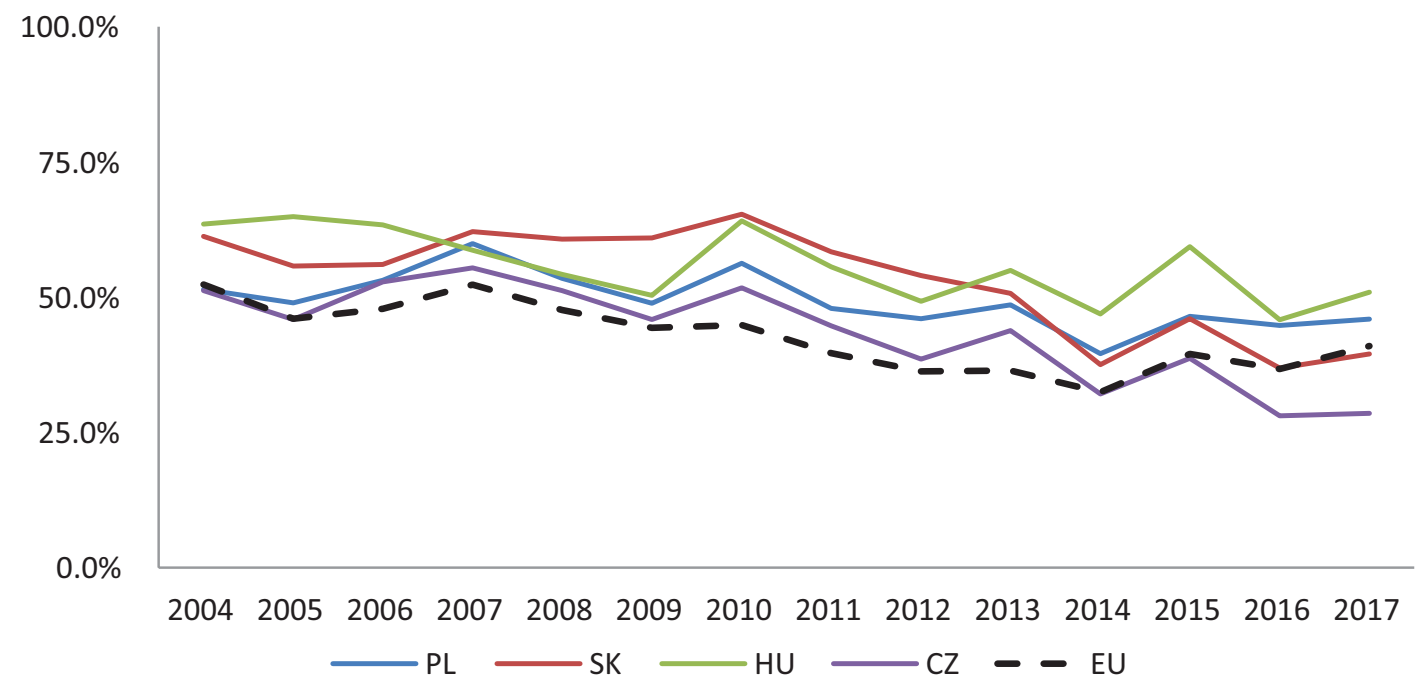

Figure 2. Trust in the EU in V4 countries between 2004 and 2017. Source: Eurobarometer. Note: Trust to EC used here as a proxy for trust to EU.

\footnotetext{
14 On voter volatility in Slovakia see Gyárfášová, Bahna and Slosiarik (2017).
} 
least (51.4\% and 51.2\% respectively). Between 2004 and 2017, trust in the EU decreased in all V4 countries but the Hungarians still have the highest levels of trust in the EU. Overall, trust in Poland and Hungary is above the EU28 average, while the trust in the Czech Republic and Slovakia is comparatively low.

The refugee crisis undermined trust in the EU (between 2015 and 2017), but it also transformed the nature of Euroscepticism. Initially, Euroscepticism was fueled by fears about the consequences of ceding sovereignty. In 2009, Euroscepticism manifested itself in opposition to the Lisbon Treaty, particularly in Poland and the Czech Republic. During the economic crisis, Euroscepticism was economically driven and directed against the oversight of the European Central Bank in Hungary. Slovak's far-right opposed bailing out Greece, since Slovakia was expected to contribute as a member of the eurozone, unlike the other three countries that are outside the eurozone. From 2015 onwards, Euroscepticism has been framed around the perception that new member states are being treated as "second-class members", particularly concerning the alleged "imposition" of refugee quotas against their will.

In the Czech Republic, the two most vocal opponents of the refugee quotas are the ANO leader Andrej Babiš and President Zeman. In Poland, PiS and the radicalright opposition Kukiz'15 are at the forefront of rejecting the EU refugee quotas. However, even the opposition party Civic Platform is luke-warm about accommodating refugees. Hungary, which has the highest level of trust in the EU among the V4 and much higher than the EU average, shows that illiberal swerving is fully compatible with positive attitudes towards the EU. Further research would be needed, however, to ascertain whether Hungarians value the EU as an idea or as a pocketbook.

Slovakia is a poster child for the positive effects of Europeanization. The country is the only Euro adopter among the V4. In August 2017, Prime Minister Fico broke with the V4 countries to openly articulate Slovakia's place at the core of deepening European integration (Jancirova, 2017). At the same time, the Slovak government's staunch opposition to migrant quotas is completely in line with the other V4 countries.

The EU playbook to thwart illiberal swerving is limited to recommendations and sanctions under Article 7 of the Lisbon Treaty. The vote must be unanimous, however. Kaczyński and Orbán have neutralized the threat of sanctions by forging a coalition to veto any Article 7 vote against each other's country. This stalemate can be only changed domestically. For now, the main focus of both Kaczyński and Orbán is to maintain public support and to limit domestic opposition.

\section{Illiberal Swerving and the Global Economic Crisis}

Looking back over the last two decades, it is tempting to associate the illiberal turn in CEE with the global economic crisis. Economic anxiety can lead to the destabi- lization of political systems, and prompt voters to punish parties by opting for anti-establishment, populist challengers (Hawkins, Read, \& Pauwels, 2017).

But with the data in hand, we can now ask about the impact of the global economic crisis on illiberal swerving in CEE. The economic crisis and the subsequent Euro crisis varied across the region. There was virtually no negative impact in terms of GDP or labor market indicators in Poland. The Czech Republic experienced a moderate economic contraction and a mild weakening of the labor market. Slovakia's labor market experienced a harsh shock coupled with a moderate economic contraction. Finally, Hungary suffered through a severe economic contraction and moderate labor market impact (Verick \& Islam, 2010, p. 29). The economic crisis was an economic stress test, but it also tested the depth of democratic consolidation.

During the economic crisis, trust in the EU in EU28 countries decreased by $8 \%$. It is no surprise that trust decreased in three of the four V4 countries: the Czech Republic (-6.5\%), Poland (-5.6\%) and Slovakia (-2.3\%). Paradoxically, in Hungary, where the effects of the crisis were the most severe, trust in the EU has strengthened (+1.4\%).

Kriesi and Pappas (2015, p. 323) argue that the economic crisis generated populist challenges to the status quo roughly commensurate with the extent of the impact of the crisis. Populism significantly rose in Hungary, a country that experienced dramatic economic contraction. Where the crisis was not as severe-such as in the Czech Republic, Poland and Slovakia-populism was very limited, they argue. This was certainly the case until a few years ago. The rise of PiS in Poland, unaffected by the crisis, and the electoral landslide of ANO in the Czech Republic, a country with the lowest unemployment rate in Europe, show that populists can thrive in decent economic conditions. Hungary, however, has undergone a sharp economic downturn, exacerbated by the existence of corrupt oligarchic networks tied to FIDESZ that have penetrated the state administration. The economic crisis certainly fueled illiberal swerving in the V4 but appears neither a necessary nor a sufficient condition for it.

\section{Conclusion}

This article investigates the "illiberal turn" in the V4 countries (Czech Republic, Hungary, Poland, Slovakia). We distinguish "turns" from "swerves", with the former representing more permanent political changes. Three reasons underline this distinction. First, despite similarities in democratic and economic performance, the V4 is a diverse group, and the broad "illiberal turn" brush obscures more than it illuminates. Second, V4 countries have demonstrated that they can overcome authoritarian inklings in the recent past (the Czech Republic after 2000, Slovakia after 1998, Poland between 2005 to 2007). Third, we remain cautiously optimistic about the state of democracy in the V4, but we consider the current situa- 
tion in Hungary to be grave. ${ }^{15}$ Moreover, we are alarmed by efforts to undermine democratic institutions and the rule of law in Poland and by the authoritarian inklings of Babiš in the Czech Republic. Yet, none of the V4 countries seem to be at immediate risk of a regime reversal to a full-blown autocracy.

Viewing recent developments in the V4 through the lenses of temporary episodic swerves offers a more nuanced perspective on the state of democracy. For illiberal swerving to become a full turn, the key conditions would need to recur over at least two electoral cycles: 1) political polarization that prevents viable consensus about the character of the democratic polity; 2 ) the capture of the courts that seeks to dismantle the rule of law and balance of power; 3) political control of the media that involves increased control of the state media, and elimination or subjection of private media; 4) legal persecution of the civil society to disable mobilization and protest; and most importantly 5) change in electoral rules and of the Constitution to permanently weaken the political opposition.

As of 2017, Hungary has fulfilled most of these conditions, whereas the Polish PiS has been only partially successful. Some swerving has occurred in the Czech Republic and Slovakia, but there is still plenty of distance from an illiberal turn. Time will soon tell whether these illiberal swerves become full-fledged illiberal turns. If FIDESZ in Hungary, PiS in Poland and ANO in the Czech Republic decisively win another election, they will implement irreversible changes that will take these countries out of the orbit of European democracies. Unpacking the illiberal turn into a series of episodes of illiberal swerves that combine executive aggrandizement and contestation of sovereignty, provides a new way of understanding current developments in the V4. Small shifts need not cause alarmism about an "illiberal turn". It is true that big trees from small acorns grow, but not all seeds bloom, and not all roots grow-for the same reason, not all illiberal swerves will become illiberal turns-because the necessary conditions are not satisfied and countervailing forces show resistance.

\section{Acknowledgments}

We thank Benjamin Stanely for his contribution to the earlier version of this article, Kirk Hawkins for suggesting the term "swerve", Aron Suba for discussions about Hungary, David Siroky for comments and Simona Patkova and Chirasree Mukherjee for research assistance. The Melikian Center at the Arizona State University Center for the Study of Religion and Conflict at ASU and the Czech Science Foundation (Project "Changes in the Perception of the Role of Government after the Crisis: The Czech Republic in Comparative Perspective", no. 16-04885S) provided financial support.

\section{Conflict of Interests}

The authors declare no conflict of interests.

\section{References}

Basta, K., \& Bustikova, L. (2016). Concession and secession: Constitutional bargaining failure in postcommunist Czechoslovakia. Swiss Political Science Review, 22(4), 470-490.

Bermeo, N. (2016). On democratic backsliding. Journal of Democracy, 27(1), 5-19.

Bernhard, M., \& Karakoç, E. (2011). Moving west or going south? Economic transformation and institutionalization in postcommunist party systems. Comparative Politics, 44(1), 1-20.

Bernhard, M. (2015). Chronic instability and the limits of path dependence. Perspectives on Politics, 13(4), 976-991.

Bertelsmann Foundation. (2016). Bertelsmann transformation index 2016. Gütersloh: Bertelsmann Foundation.

Bustikova, L. (2014). Revenge of the radical right. Comparative Political Studies, 47(12), 1738-1765.

Bustikova, L. (2015). The democratization of hostility: Minorities and radical right actors after the fall of communism. In M. Minkenberg (Ed.), Transforming the transformation (pp. 58-79). London: Routledge.

Bustikova, L. (in press). The radical right in Eastern Europe. In J. Rydgren (Ed.), The Oxford handbook of the radical right (pp. 565-581). New York, NY: Oxford University Press.

Bustikova, L., \& Guasti, P. (2012). Hate thy imaginary neighbour: An analysis of anti-Semitism in Slovakia. Journal for the Study of Anti-Semitism, 4(2), 469-493.

Chambers, S., \& Kopstein, J. (2001). Bad civil society. Political Theory, 29(6), 838-866.

Dawson, J., \& Hanley, S. (2016). The fading mirage of the "liberal consensus". Journal of Democracy, 27(1), 20-34.

Dearden, L. (2017, March 4). Hungarian border guards 'taking selfies with beaten migrants' as crackdown against refugees intensifies. Independent. Retrieved from http://www.independent.co.uk/news/world/ europe/refugee-crisis-hungary-border-police-guards -fence-beating-asylum-seekers-migrants-serbia-push -back-a7610411.html

Deegan-Krause, K., \& Haughton, T. (2009). Toward a more useful conceptualization of populism: Types and degrees of populist appeals in the case of Slovakia. Politics \& Policy, 37(4), 821-841.

Dyke, J. (2017, November 6). In Poland last month, an act of self-sacrifice on a par with Jan Palach. The Guardian. Retrieved from https://www.theguardian. com/world/2017/nov/06/in-poland-last-month-anact-of-self-sacrifice-on-a-par-with-jan-palach

\footnotetext{
15 The Bertelsmann Transformation Index ranks Hungary as a defective democracy, unlike its V4 counterparts, which are ranked as democracies in consolidation (Bertelsmann Foundation, 2016).
} 
Epstein, R. A., \& Sedelmeier, U. (2008). Beyond conditionality: International institutions in postcommunist Europe after enlargement. Journal of European Public Policy, 15(6), 795-805.

Greskovits, B. (2015). The hollowing and backsliding of democracy in East Central Europe. Global Policy, 6(S1), 28-37.

Grzymala-Busse, A. (2017). Global populisms and their impact. Slavic Review, 76(S1), S3-S8.

Grzymala-Busse, A., \& Innes, A. (2003). Great expectations: The EU and domestic political competition in East Central Europe. East European Politics and Societies, 17(1), 64-73.

Guasti, P. (2016). Development of citizen participation in Central and Eastern Europe after the EU enlargement and economic crises. Communist and PostCommunist Studies, 49(3), 219-231.

Guasti, P. (2017, September). Left and right and beyond: Analyzing representative claims in the Czech Republic. Paper presented at the ECPR General Conference, Oslo, Norway.

Guasti, P., Siroky, D., \& Stockemer, D. (2017). Judgment without justice: On the efficacy of the European human rights regime. Democratization, 24(2), 226-243.

Gyárfášová, O., Bahna, M., \& Slosiarik, M. (2017). Sila nestálosti: volatilita voličov na Slovensku vo vol'bách 2016 [The strength of instability: Voter volatility in 2016 Slovak elections]. Středoevropské politické studie, 19(1), 1-24.

Hagopian, F. (2005). Government performance, political representation, and public perceptions of contemporary democracy in Latin America. In F. Hagopian \& S. P. Mainwaring (Eds.), The third wave of democratization in Latin America: Advances and setbacks (pp. 328-330). Cambridge: Cambridge University Press.

Hanley, S., \& Sikk, A. (2016). Economy, corruption or floating voters? Explaining the breakthroughs of anti-establishment reform parties in eastern Europe. Party Politics, 22(4), 522-533.

Hanley, S., \& Vachudova, M. (2017). Backsliding by the backdoor? Hollow political competition and the concentration of power in postcommunist Europe. Paper presented at the CES conference, Glasgow, UK.

Haughton, T., \& Deegan-Krause, K. (2015). Hurricane season: Systems of instability in central and east European party politics. East European Politics and Societies, 29(1), 61-80.

Hawkins, K., Read, M., \& Pauwels, T. (2017). Populism and its causes. In C. R. Kaltwasser, P. A. Taggart, P. O. Espejo, \& P. Ostiguy (Eds.), Oxford handbook of populism (pp. 267-286). Oxford: Oxford University Press.

Huq, A., \& Ginsburg, T. (in press). How to lose a constitutional democracy. UCLA Law Review, 65.

Jancirova, T. (2017, August 15). Slovakia's future is with core EU, not Eurosceptic eastern nations: PM. Reuters. Retrieved from https://www.reuters.com/ article/us-slovakia-politics-eu-idUSKCN1AV1YY

Jasiewicz, K. (2007). Is Central Europe backsliding?
The political-party landscape. Journal of Democracy, 18(4), 26-33.

Jenne, E. K., \& Mudde, C. (2012). Can outsiders help? Journal of Democracy, 23(3), 147-155.

Kitschelt, H., Mansfeldova, Z., Markowski, R., \& Toka, G. (1999). Post-communist party systems: Competition, representation, and inter-party cooperation. Cambridge: Cambridge University Press.

Kopecky, P., \& Mudde, C. (Eds.). (2003). Uncivil society? Contentious politics in post-communist Europe. London: Routledge.

Kriesi, H., \& Pappas, T. S. (Eds.). (2015). European populism in the shadow of the great recession. Colchester: ECPR Press.

Levitz, P., \& Pop-Eleches, G. (2010). Why no backsliding? The European Union's impact on democracy and governance before and after accession. Comparative Political Studies, 43(4), 457-485.

Lewis, P. G. (2006). The EU and party politics in central and eastern Europe: Questions and issues. In P. G. Lewis \& Z. Mansfeldova (Eds.), The European Union and party politics in central and eastern Europe (pp. 1-19). Houndmills, Basingstoke and New York, NY: Palgrave MacMillan.

Malová, D., Rybar, M., Bilcik, V., Lastic, E., Lisonova, Z., Misik, M., \& Pasiak, M. (2010). From listening to action? New member states in the European Union. Bratislava: Devin Printing House.

Medecins sans Frontieres. (2016, July 22). Serbia: Sharp increase in violence against migrants since border closures in the Balkans. Medecins sans Frontieres. Retrieved from http://www.msf.org/en/article/serbiasharp-increase-violence-against-migrants-border-clos ures-balkans

Nalepa, M. (2017, November 16). As Poland's nationalists take the spotlight, notice the protesters. Chicago Tribune. Retrieved from http://www.chicagotribune. com/news/opinion/commentary/ct-perspec-polandindependence-day-march-szczesny-1117-20171116story.html

Nolan, D. (2016, June 19). Hungarian prime minister Viktor Orbán investigated over $€ 2 \mathrm{~m}$ EU funding spent on 'absurd' vintage train line. The Telegraph. Retrieved from http://www.telegraph.co.uk/news/ 2016/06/19/hungarian-prime-minister-viktor-orbaninvestigated-over-2m-eu-fu

Pop-Eleches, G., \& Tucker, J. (2017). Communism's shadow: Historical legacies and contemporary political attitudes. Princeton, NJ: Princeton University Press.

Rupnik, J. (2007). From democracy fatigue to populist backlash. Journal of Democracy, 18(4), 17-25.

Rupnik, J. (2016). Surging illiberalism in the east. Journal of Democracy, 27(4), 77-87.

Schimmelfennig, F. (2005). Strategic calculation and international socialization: Membership incentives, party constellations, and sustained compliance in Central and Eastern Europe. International Organiza- 
tion, 59(4), 827-860.

Schlipphak, B., \& Treib, O. (2017). Playing the blame game on Brussels: The domestic political effects of EU interventions against democratic backsliding. Journal of European Public Policy, 24(3), 352-365.

Shelef, N. (2010). Evolving nationalism. Ithaca, NY: Cornell University Press.

Siroky, D., \& Cuffe, J. (2015). Lost autonomy, nationalism and separatism. Comparative Political Studies, 48(1), 3-34.

Stanley, B. (2008). The thin ideology of populism. Journal of Political Ideologies, 13(1), 95-110.

Stanley, B., \& Czesnik, M. (2016). Poland's Palikot movement: Voice of the disenchanted, missing ideological link or more of the same? Party Politics, 22(6), 705-718.

Than, K., \& Dunai, M. (2017, June 13). Hungary tightens rules on foreign-funded NGOs, defying EU. Reuters. Retrieved from https://af.reuters.com/article/world News/idAFKBN19417T

Thelen, K. (2003). How institutions evolve: Insights from comparative historical analysis. In J. Mahoney \& D.
Rueschemeyer (Eds.), Comparative historical analysis in the social sciences (pp. 208-241). Cambridge: Cambridge University Press.

United Nations High Commissioner for Refugees. (2017, May 15). UN rights experts urge Hungary to withdraw Bill on foreign funding to NGOs. UNHCR. Retrieved from http://www.ohchr.org/EN/NewsEvents/ Pages/DisplayNews.aspx?NewsID=21617\&LangID=E

Vachudova, M. A. (2005). Europe undivided: Democracy, leverage, and integration after communism. Oxford: Oxford University Press.

Vachudova, M. A. (2015). External actors and regime change: How post-communism transformed comparative politics. East European Politics and Societies, 29(2), 519-530.

Verick, S., \& Islam, I. (2010). The great recession of 20082009: Causes, consequences and policy responses (IZA Discussion Paper No. 4934). Bonn: Institute for the Study of Labor.

Zalan, E. (2016, January 8). How to build an illiberal democracy in the EU. EU observer. Retrieved from https://euobserver.com/political/131723

\section{About the Authors}

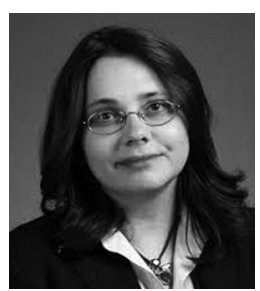

Lenka Bustikova is an Assistant Professor in the School of Politics and Global Studies and an affiliate of the Melikian Center for Russian, Eurasian and East European Studies at Arizona State University. Her research focuses on party politics, voting behavior, clientelism, and state capacity. She is the recipient of the 2015 Best Article Prize, awarded by the American Political Science Association's European Politics and Society Section, for her article "Revenge of the Radical Right", and also the recipient of the 2017 Best Paper Prize, awarded by the American Political Science Association's Comparative Democratization Section, for her paper co-authored with Cristina Corduneanu-Huci "Patronage, Trust and State Capacity: The Historical Trajectories of Clientelism".

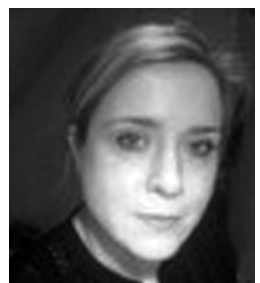

Petra Guasti is a Postdoctoral Research Fellow at the Research Unit "Democratic Innovations" at Goethe University Frankfurt (Germany). Her main research focus is democracy, more specifically the growing tension within the system of representative democracy in respect to its legitimacy. She studies structures, actors, and processes that enable more participation of citizens, leading to more inclusiveness of representative democracy. Her work was published in Democratization, Communist and Post-Communist Studies and European Political Science. 